\title{
Direitos, obrigações e responsabilidades no processo editorial científico
}

\author{
Cristina Muccioli, Mauro Campos, Mauro Goldchmit, Paulo E. C. Dantas, Samir J. Bechara, Vital Paulino Costa
}

O processo editorial científico representa um rico e fascinante campo no plano dos direitos, obrigações e responsabilidades envolvidas. Vale lembrar que o caráter do processo editorial científico ultrapassa a mera atividade gráfica periódica. Diferente de outros meios de comunicação impressa, a atividade da revista científica faz algo mais que noticiar um fato, acontecimento ou opinião do mundo da ciência médica. A revista científica torna público, sim e por excelência, o conhecimento médico original.

Neste diapasão, incidem sobre a atividade da revista científica, de forma genérica, os regulamentos aplicáveis aos meios de comunicação. De maneira particular, adicionam-se as regras do direito autoral, a proteger o conhecimento médico original contido no material submetido à publicação.

$\mathrm{O}$ processo editorial científico inicia-se por iniciativa do autor, submetendo à revista o material a ser publicado. Nesta relação jurídica, de natureza contratual, o autor e a revista obrigam-se mutuamente. A revista obriga-se a prestar uma revisão por pares, idônea, imparcial e no melhor interesse da ciência médica, dentro de prazos consensualmente definidos. $\mathrm{O}$ autor, por seu turno, obriga-se a apresentar o conhecimento médico original a ser publicado, legítimo, isento de fraudes, gerado por métodos científicos adequados, cumprindo preceitos éticos, tais como o escrutínio das comissões de ética.

Em torno desta relação jurídica principal entre o autor e a revista científica, estabelecem-se relações jurídicas acessórias, em que figuram terceiros interessados nos efeitos da publicação do material científico submetido pelo autor. Instituições, como universidades ou hospitais universitários, públicos ou privados, onde o conhecimento original foi gerado e que têm interesse na publicação em benefício de sua imagem. Empresas privadas, como os laboratórios patrocinadores dos estudos clínicos ou experimentais, têm interesse na publicação como etapa relevante de sua estratégia empresarial. Agências públicas de fomento científico têm na publicação em revistas científicas conceituadas a contrapartida pelos recursos cedidos à realização da pesquisa geradora do conhecimento médico original. Não por menos, aparece o poder público como terceiro interessado na segurança e proteção da população alvo das novas terapêuticas.

Em havendo direitos, relações contratuais, agentes interessados e obrigações assumidas no processo editorial científico e, especialmente, considerando ser o conhecimento médico original um bem de valor econômico, segue haver potenciais responsabilidades. Da revista, enquanto guardiã dos direitos autorais cedidos pelo autor ao submeter o material para publicação. Dos autores, em face de materiais gerados e publicados mediante fraude, causando erro ou dano a terceiros de boa fé. Dos editores, a quem a revista subroga os direitos autorais cedidos pelo autor, responsáveis por gerenciar os prazos e as decisões de mérito sobre a aceitação ou rejeição do material submetido. Dos revisores, a quem os editores confiam a análise do conteúdo científico do material submetido.

Houve um tempo em que a revista científica prestava-se precipuamente à difusão do conhecimento e atualização acadêmica, no âmbito de uma comunidade restrita. Desde então, esta função muito se modificou, incorporando dimensões e interesses científicos, econômicos, jurídicos e políticos. Daí a relevância e necessidade da modernização e segurança dos processos de editoração científica, assim como do comprometimento e confiabilidade das pessoas envolvidas, particularmente num momento em que, como no caso dos Arquivos, a revista ganha exposição mundial através do Index Medicus.
Vislte a slte eletronica dos ABD

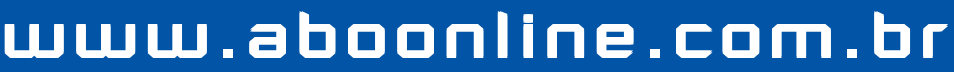

